\title{
Celebrity worship and body image among young girls fans of K-pop girl groups
}

\author{
Kadek Ayu Anatasya Divina Tresna, Monique Elizabeth Sukamto, Marselius Sampe \\ Tondok
}

Faculty of Psychology, Universitas Surabaya, Indonesia

Corresponding author: monique@staff.ubaya.ac.id

\section{ARTICLE INFO}

Article history

Received January 6, 2021

Revised July 15, 2021

Accepted July 22, 2021

Keywords

adolescent;

body image;

celebrity worship;

K-pop girl groups.

\section{ABSTRACT}

Currently, K-pop girl groups are some of the favorite celebrities who often become the ideal standard for young girls. K-pop girl figures are often displayed with ideal body standards, such as having a slim body, white skin, thin face, and high nose, thus making fans adore and want to have a physical appearance like their idol. This study aimed to examine the relationship between celebrity worship and body image among female adolescents who idolized K-pop girl groups. A sample of 414 female adolescents aged 18-22 years participated online in the current study by filling in the Celebrity Attitude Scale (CAS) and the Multidimensional Body-Self Relation Questionnaire-Appearance Scale (MBSRQ-AS). Results showed that the entertainment-social aspect of celebrity worship proved a significant positive correlation with the appearance orientation dimension of body image. In contrast, the borderline-pathological aspect had a significant negative correlation with the body areas satisfaction dimension. Nonetheless, the intense personal aspect of celebrity worship did not correlate significantly with all dimensions of body image among young girls fans of K-pop girl groups. Thus, each level of celebrity worship correlates differently with each dimension of body image. Entertainment-social is the most common celebrity worship among adolescent girls fans of K-pop girl groups and affects young girls' body image by increasing their attention to appearance.

\section{Introduction}

Adolescence is a transition period from childhood to adulthood, including physical, socioemotional, and cognitive changes (Santrock, 2007). In adolescence, individuals have several developmental tasks related to their physical and psychological maturity. One thing that must be fulfilled is that adolescents can accept their physical conditions. However, in reality, adolescents, particularly girls, possess a sense of dissatisfaction with their body shape. Adolescents' dissatisfaction with their body shape increases from junior high school to senior high school and continues to increase until late adolescence and early adulthood (Bucchianeri, Arikan, Hannan, Eisenberg, \& Neumark-Sztainer, 2013).

According to Burns (1993), body image is the perception of an individual body shape. Each individual has the ideal body standard. Adolescent girls have body standards 
that are more concerned with physical appearance and a proportional body shape (Denich \& Ifdil, 2015). Body image consists of five dimensions: appearance orientation, appearance evaluation, body-areas satisfaction, self-classified weight, and overweight preoccupation (Cash, 2000). Appearance evaluation is the feelings of attractiveness or unattractiveness and satisfaction or dissatisfaction with one's physical appearance. Appearance orientation shows how individuals consider important and pay attention to their physical appearance and individual efforts to improve their appearance. Body-areas satisfaction focuses on individuals' satisfaction with their specific body parts, such as face, chest, stomach, buttocks, shoulders, and so on. Overweight preoccupation focuses on individuals' anxiety about fatness, dieting behavior, weight vigilance, and eating restraint. Self-classified weight is an individual's perception of their weight, whether classified as underweight, normal, or overweight.

Factors that influence body image come from family, biological, media, and peer factors (Burns, 1993). Media is one of the most influential factors in body image. The media presents pictures of female figures' ideal body shape, which can affect the individual body image. The negative impact of the media causes individuals to overstate the ideal bodies so that individuals will always compare their body shape, go on a diet, and suffer from eating disorders. Body dissatisfaction in women increases when individuals compare their body shape with celebrities who possess slim bodies (Heinberg \& Thompson, 1992). The psychological influence of the media gives rise to parasocial relationships with figures in the media. A parasocial relationship is a one-way relationship that the fans imagine with their idols that can influence adolescents' behaviors (Giles \& Maltby, 2004).

Lately, in Indonesia, the Korean wave or Hallyu phenomenon is frequently seen as a term for Korean fever related to the entertainment world of South Korea like films, dramas, music, fashion, food, and its traditional culture (Hennida, 2013). Korean pop or K-pop, an enormously popular genre of music from South Korea, is increasingly known in Indonesia. Adolescents dominate K-pop fans in Indonesia. A survey conducted of $100 \mathrm{~K}$-pop fans showed around 57\% of respondents were in their teens and early adulthood (12-20 years old), $42 \%$ of respondents were 21-30 years old, and 1\% were aged over 30 years (Nurani, 2017). The K-pop music genre is well known for both boy and girl groups, and this research focuses on girl groups. Girl groups' figures are often displayed with ideal body standards, such as having a slim body, tall, fair skin, thin face, and high nose, encouraging girl groups fans to look like their idols constantly.

The above phenomenon shows fans' admiration for their idols and illustrates a form of celebrity worship. Celebrity worship is defined as a parasocial relationship or one-sided relationship, which means that the individual knows about the celebrity but not the other way around (Maltby, Giles, Barber, \& McCutcheon, 2005). Maltby et al. (2005) distinguish celebrity worship into three aspects according to its level: entertainment-social, intense-personal, and borderline-pathological. Entertainment-social is the lowest level of celebrity worship related to a celebrity's ability to entertain and attract the attention of his or her fans. The intense-personal aspect involves a feeling that is intense and compulsive toward celebrities. Borderline-pathological is the most extreme level of celebrity worship, which is indicated by the willingness to do anything for a favorite celebrity.

Based on a previous study by Maltby et al. (2005), there was a significant relationship between the intense-personal aspect of celebrity worship and body image in adolescent girls. Furthermore, a study by Jung and Hwang (2016) among female college students showed that attitudes toward favorite celebrities were positively associated with acceptance for cosmetic surgery, which is also a body image issue. 
The two previous studies of celebrity worship have not been conducted on fans of any particular celebrity. This study will examine the relationship between celebrity worship and body image, especially among young girls who adore K-pop girl groups. In contrast to previous studies that examined overall body image, this study will examine the relationship between each level of celebrity worship and each dimension of body image. The researcher wants to explore the peculiarity of the relationship between each level of celebrity worship and each dimension of body image in young girls who are fans of K-pop girl groups. This study focuses on Korean pop girl groups as these groups are a very popular music genre among young girls in Indonesia today.

\section{Method}

This study used a quantitative research method. Data were collected online using questionnaires, the Multidimensional Body-Self Relation Questionnaire-Appearance Scale (MBSRQ-AS) developed by Cash (2000), and the Celebrity Attitude Scale developed by Maltby et al. (2005). The researcher asked permission to use the Celebrity Attitude Scale (CAS) and the Multidimensional Body Self-Relation Questionnaire-Appearance Scale (MBSRQ-AS) from the authors of the two scales. The researcher forward-translated the two scales from English (the original version) into Indonesian and then back-translated into English to ensure that the Indonesian version of each scale had the same meaning as the original version. In addition, the researcher also asked for a Content Validity Ratio (CVR) assessment from the experts in psychology. According to Lawshe's CVR (Wilson, Pan, \& Schumsky, 2012), an item is said to have good content validity if the CVR Index is $\geq .5$. The CVI values in this study were .900 for MBSRQ-AS and .890 for CAS. This study also used an open questionnaire to explore the characteristics of the participants. A set of questionnaires that the experts in psychology have approved was then compiled in a google-form and distributed online.

\section{Participants}

Participants in this study were recruited online. The researchers distributed the questionnaire on the social media platform Twitter using google forms link through K-pop girl groups fans. Participants in this study were 414 female adolescents aged 18 to 22 years old and Korean pop girl groups fans. Table 1 shows the characteristics of participants.

Table 1

Characteristics of Participants $(N=414)$

\begin{tabular}{|c|c|c|c|c|c|}
\hline Characteristic & Frequency & $\%$ & Characteristic & Frequency & $\%$ \\
\hline Age (years) & & & Education Level & & \\
\hline 18 & 69 & 16.7 & Senior High School & 21 & 5.1 \\
\hline 19 & 76 & 18.4 & Diploma III & 24 & 5.8 \\
\hline 20 & 105 & 25.4 & Diploma IV & 14 & 3.4 \\
\hline 21 & 87 & 21.0 & Bachelor Degree & 296 & 71.5 \\
\hline 22 & 77 & 18.6 & Not choosing any & 59 & 14.3 \\
\hline$B M I$ & & & Listening to $K$-рор & & \\
\hline Underweight $(<18.5)$ & 113 & 27.3 & group's songs & & \\
\hline Normal weight $(18.5-22.9)$ & 171 & 41.3 & Always & 295 & 71.3 \\
\hline Overweight (23-24.9) & 54 & 13 & Often & 99 & 23.9 \\
\hline Obese $(\geq 25.0)$ & 76 & 18.4 & Sometimes & 20 & 4.8 \\
\hline
\end{tabular}


Table 1 (continue)

Characteristics of Participants $(N=414)$

\begin{tabular}{|c|c|c|c|c|c|}
\hline Characteristic & Frequency & $\%$ & Characteristic & Frequency & $\%$ \\
\hline Reasons for worshipping $K$-pop & & & Length of worshipping $K$ - & & \\
\hline girl groups & & & pop girl groups & & \\
\hline Excellent vocals & 330 & 79.7 & Less than 1 year & 47 & 11.4 \\
\hline Attractive appearance and face & 297 & 71.7 & 1 year & 63 & 15.2 \\
\hline Excellent songs & 42 & 10.1 & 2 years & 66 & 15.9 \\
\hline Multitalented & 39 & 9.4 & More than 2 years & 238 & 57.5 \\
\hline Many friends idolize & 29 & 7 & & & \\
\hline Personality & 18 & 4.3 & & & \\
\hline Unique concept & 11 & 2.7 & & & \\
\hline Nice and powerful dance & 6 & 1.4 & & & \\
\hline Desiring a body like an idol & & & Efforts if feeling dissatisfied & & \\
\hline Always & 68 & 16.4 & with body shape & & \\
\hline Often & 135 & 32.6 & Exercising & 147 & 35.5 \\
\hline Sometimes & 122 & 29.5 & Reducing food portion & 144 & 34.8 \\
\hline Rarely & 58 & 14.0 & Fasting & 33 & 8 \\
\hline Never & 31 & 7.5 & Taking weight loss pills & 10 & 2.4 \\
\hline Comparing self with idol & & & Looking for information & & \\
\hline Always & 23 & 3.0 & about K-pop girl groups & & \\
\hline Often & 74 & 9.6 & Always & 277 & 66.9 \\
\hline Sometimes & 113 & 15.2 & Often & 110 & 26.6 \\
\hline Rarely & 103 & 13.4 & Sometimes & 19 & 4.6 \\
\hline Never & 97 & 12.6 & Rarely & 8 & 1.9 \\
\hline Media to access information about & & & Watching idol's V-Live & & \\
\hline K-pop girl groups & & & Always & 139 & 33.6 \\
\hline YouTube & 365 & 88.2 & Often & 130 & 31.4 \\
\hline Twitter & 362 & 87.4 & Sometimes & 78 & 18.8 \\
\hline Instagram & 346 & 83.6 & Rarely & 50 & 12.1 \\
\hline V-Live & 171 & 41.3 & Never & 17 & 4.1 \\
\hline Facebook & 22 & 5.3 & & & \\
\hline Buying K-pop girl group's albums & & & Streaming $\quad K-p o p$ & & \\
\hline Always & 48 & 11.6 & group's music video & & \\
\hline Often & 64 & 15.5 & Always & 142 & 34.3 \\
\hline Sometimes & 73 & 17.6 & Often & 133 & 32.1 \\
\hline Rarely & 90 & 21.7 & Sometimes & 88 & 21.3 \\
\hline Never & 139 & 33.6 & Rarely & 44 & 10.6 \\
\hline & & & Never & 7 & 1.7 \\
\hline $\begin{array}{l}\text { Buying K-pop girl group's goods or } \\
\text { merchandise }\end{array}$ & & & & & \\
\hline Always & 44 & 31.9 & & & \\
\hline Often & 59 & 22.2 & & & \\
\hline Sometimes & 87 & 21.0 & & & \\
\hline Rarely & 92 & 14.3 & & & \\
\hline Never & 132 & 10.6 & & & \\
\hline
\end{tabular}

\section{Instruments}

Multidimensional Body-Self Relation Questionnaire-Appearance Scale (MBSRQ-AS)

The MBSRQ-AS is a 34-item scale (Cash, 2000), but there were five items deleted in the current study because the item discrimination index was less than .250 . This scale consists of five dimensions as follows. 
The appearance evaluation dimension consists of 6-items. Examples of items are "My body is sexually appealing" and "I like my looks just the way they are". Each item is rated on a 5-scale ranging from 1 (definitely disagree) to 5 (definitely agree). The reliability coefficient for the current sample was .762, with the item discrimination index ranging from .296 to .683 .

The appearance orientation dimension consists of 8-items. Each item is rated on a 5 -scale ranging from 1 (definitely disagree) to 5 (definitely agree). The sample of items are "Before going out in public, I always notice how I look" and "Before going out, I usually spend a lot of time getting ready". The reliability coefficient for the current sample was .753 , with the item discrimination index ranging from .342 to .581 .

The body-areas satisfaction dimension consists of 9-items. Each item is rated on a 5 -scale from 1 (very dissatisfied) to 5 (very satisfied). The sample of items are "Face (facial features, complexion)" and "Lower torso (buttocks, hips, thighs, and legs". The reliability coefficient in the current sample was .733, with the item discrimination index ranging from .261 to .657 .

The overweight preoccupation dimension consists of 4-items. Examples of items are "I constantly worry about being or becoming fat" and "I am very conscious of even small changes in my weight". Each item is rated on a 5-scale ranging from 1 (definitely disagree) to 5 (definitely agree). The reliability coefficient for the sample in this study was .804, with the item discrimination index ranging from .486 to .662 .

The self-classified weight dimension consists of 2 items. Each item is rated on a 5scale from 1 (very underweight) to 2 (very overweight). The items are "I think I am very....." and "From looking at me, most people would think I am....". The reliability coefficient in the current study was .905 .

\section{Celebrity Attitude Scale (CAS)}

The CAS used in this study was developed by Maltby et al. (2005) and consisted of 22 items. In this study, the items were modified for K-pop fans by changing the word "celebrity" to "K-pop girl groups". The items are rated on a 5-point scale with responses ranging from 1 (strongly disagree) to 5 (strongly agree). The items of this scale are categorized into three aspects according to the level of celebrity worship, namely: entertainment-social, intense-personal, and borderline-pathological.

The entertainment-social aspect measures the attitudes and behaviors of fans to their favorite K-pop girl groups. Examples of the items are "My friends and I like to discuss what my favorite K-pop girl groups have done" and "I enjoy watching, reading, or listening to my favorite K-pop girl groups because it means a good time". It consists of 10items. The reliability coefficient for the sample in this study was .797 , with the item discrimination index ranging from .320 to .576 .

The intense-personal consists of 9-items. Examples of the items are "When my favorite K-pop girl groups dies, I will feel like dying too" and "The successes of my favorite K-pop girl groups are my successes too). The reliability coefficient for the current study was .820 , with the item discrimination index ranging from .356 to .669 .

The borderline-pathological consists of 3-items. An example of the item is "If I were lucky enough to meet my favorite K-pop girl groups and they asked me to do something illegal as a favor, I would probably do it". The reliability coefficient for the current sample was .502, with the item discrimination index ranging from .290 to .356. Alphas for the borderline-pathological tend to be lower because this aspect is the shortest of the three aspects, comprising few items (McCutcheon, Scott, Aruguete, \& Parker, 2006). 


\section{Data Analysis}

The collected data were imported into SPSS version 24.0. Spearman's correlation coefficient analyses were conducted to test the correlations between aspects of the Celebrity Attitude Scale (CAS) and dimensions of the Multidimensional Body-Self Relation Questionnaire-Appearance Scale (MBSRQ-AS).

In this study, the data distribution is not normally distributed because the significance value is less than .05 . Therefore, hypothesis testing used a non-parametric test (Spearman correlation). The hypothesis is accepted if the significance value $(\mathrm{p})<.05$.

\section{Results}

Table 2

\section{Correlation of Celebrity Worship and Body Image}

\begin{tabular}{cccc}
\hline \multirow{2}{*}{$\begin{array}{c}\text { Dimensions of } \\
\text { Body Image }\end{array}$} & \multicolumn{3}{c}{$\begin{array}{c}\text { Aspects of Celebrity } \\
\text { Worship }\end{array}$} \\
\cline { 2 - 4 } & $\begin{array}{c}\text { Entertainment- } \\
\text { Social }\end{array}$ & Intense-Personal & Borderline-Pathological \\
\hline Appearance Evaluation & & .121 & -.016 \\
$\mathrm{r}$ & .051 & .076 & .740 \\
Sig. & .304 & .043 & .305 \\
Appearance Orientation & $.108^{*}$ & .381 & .051 \\
$\mathrm{r}$ & .028 & .036 & $-.133^{* *}$ \\
Sig. & & .467 & .007 \\
Body-Areas Satisfaction & -.021 & .055 & .081 \\
$\mathrm{r}$ & .671 & .262 & .101 \\
Sig. & .052 & & -.005 \\
Overweight Preoccupation & .288 & -.041 & .923 \\
$\mathrm{r}$ & & .401 & \\
Sig. & -.089 & &
\end{tabular}

* $p<.05$ (2-tailed)

$* * p<.01(2$-tailed $)$

Based on Table 2, the correlation value between the entertainment social and appearance orientation was .108 with a significance value of .028 (Sig. $<.05$ ), which means a significant positive correlation between entertainment social and appearance orientation. The significance value of the correlation between intense-personal and appearance orientation and borderline-pathological and appearance orientation were insignificant (Sig. $>$.05), which meant that the intense-personal and borderline-pathological aspects were not significantly correlated with the appearance orientation dimension.

The correlation between borderline-pathological and body-area satisfaction is -.133 (Sig. < .05). This result means that there is a significant negative correlation between borderline-pathological and body area satisfaction. The higher the borderline-pathological aspect, the lower the individual's body satisfaction, which means the individual is increasingly dissatisfied with the size or appearance of some body parts. The three aspects of celebrity worship were not significantly correlated with three of five dimensions of body image: appearance evaluation, overweight preoccupation, and self-classified weight. 
Table 3

Cross-Tabulation between BMI and Self-Classified Weight

\begin{tabular}{|c|c|c|c|c|c|c|}
\hline \multirow{2}{*}{ BMI } & \multicolumn{5}{|c|}{ Self-Classified Weight } & \multirow{2}{*}{ Total } \\
\hline & VUW & UW & NW & OW & VOW & \\
\hline \multirow[t]{2}{*}{ Underweight } & 26 & 53 & 31 & 2 & 1 & 113 \\
\hline & $23 \%$ & $46.9 \%$ & $27.4 \%$ & $1.8 \%$ & $0.9 \%$ & $100 \%$ \\
\hline \multirow[t]{2}{*}{ Normal weight } & 3 & 10 & 87 & 64 & 7 & 171 \\
\hline & $1.8 \%$ & $5.8 \%$ & $50.9 \%$ & $37.4 \%$ & $4.1 \%$ & $100 \%$ \\
\hline \multirow[t]{2}{*}{ Overweight } & 0 & 1 & 7 & 36 & 10 & 54 \\
\hline & $0 \%$ & $1.9 \%$ & $13.2 \%$ & $66.7 \%$ & $18.9 \%$ & $100 \%$ \\
\hline \multirow[t]{2}{*}{ Obese } & 1 & 0 & 3 & 41 & 31 & 76 \\
\hline & $1.3 \%$ & $0 \%$ & $3.9 \%$ & $53.9 \%$ & $40.8 \%$ & $100 \%$ \\
\hline
\end{tabular}

$\mathrm{VUW}=$ very underweight, $\mathrm{UW}=$ underweight, $\mathrm{NW}=$ normal weight, $\mathrm{OW}=$ overweight, $\mathrm{VOW}=$ very overweight

Table 3 shows the cross-tabulation between the participants' body mass index (BMI) and self-classified weight dimension. The participants' self-classified weights were likely to suit the BMIs, except for obese, more participants classified their weight overweight $(53.9 \%)$ than very overweight $(40.8 \%)$.

Table 4

Median Analysis of Body Image

\begin{tabular}{lccc}
\hline \multicolumn{1}{c}{ Dimension } & Minimum & Maximum & Median \\
\hline Appearance Evaluation & 1 & 5 & 3 \\
Appearance Orientation & 1 & 5 & 4 \\
Body Areas Satisfaction & 1 & 5 & 3 \\
Overweight Preoccupation & 1 & 5 & 3 \\
Self-Classified Weight & 1 & 5 & 3 \\
\hline
\end{tabular}

Table 4 shows the median value of the appearance orientation dimension was higher than the other four dimensions of body image. Those were in the moderate category.

Table 5

Median Analysis of Celebrity Worship

\begin{tabular}{lccc}
\hline \multicolumn{1}{c}{ Aspect } & Minimum & Maximum & Median \\
\hline Entertainment-Social & 1 & 5 & 4 \\
Intense-Personal & 1 & 5 & 3 \\
Borderline-Pathological & 1 & 5 & 2 \\
\hline
\end{tabular}

Table 5 shows the median value of the entertainment-social aspect was the highest. In contrast, the median value of the borderline-pathological aspect was the lowest compared to the other two aspects of celebrity worship.

\section{Discussion}

The present study aimed to test the correlation between the level of celebrity worship and dimensions of body image among female adolescent fans of K-pop girl groups. Of the most interesting findings was the significant positive correlation between the entertainment-social aspect of celebrity worship and the appearance orientation dimension of body image. Thus, adolescent girls who adored K-pop girl groups for their ability to entertain and attract attention would place more importance and attention on their appearance and strive to improve the way they dress and groom. 
One of the adolescent characteristics in seeking identity is idolatry. Greene and Adams-Price (1990) suggested that adolescents chose a celebrity such as a pop singer to be their idol or role model. The appearance was one of the reasons adolescents admired their idols which caused modeling in everyday behaviors, including clothing styles (Faujiah, 2018). A study on South Korean female college students found that women made social comparisons by analyzing the appearances in the media and making judgments about themselves (Choi, 2018).

The finding of this current study is quite in line with the result of Noky (2015) among a K-pop Community, UCEE, in Solo, which showed a significant correlation between the entertainment-social aspect of celebrity worship and body image. The main difference was that Noky (2015) examined body image as an overall concept consisting of appearance evaluation, body areas satisfaction, anxiety about being fat, and body categorization, while in this study, body image was examined separately based on its five dimensions. Therefore, Noky (2015) found a negative correlation between the entertainment-social aspect and body image. Whereas in this current study, when the entertainment-social aspect was only correlated with the appearance orientation dimension of body image, it turned out to show a positive correlation.

This study also found that the borderline-pathological aspect of celebrity worship had a significant negative correlation with the body-areas satisfaction dimension of body image. The borderline-pathological aspect is such an extreme level of celebrity worship that it can encourage fans to do anything uncontrollably, including trying to have physical characteristics that resemble their favorite celebrity (Maltby et al., 2005; McCutcheon, Lange, \& Houran, 2002). As a result, this type of worship could reduce the satisfaction and acceptance of K-pop girl groups fans toward the size or appearance of their body parts. This finding was in line with a previous study (Kusuma \& Yuliawati, 2013) which also showed a negative correlation between the borderline-pathological aspect of celebrity worship and self-esteem because fans would do anything for their idols and imitate their idol behavior excessively.

The intense personal aspect of celebrity worship did not significantly correlate with all dimensions of the body image of K-pop girl groups fans. These findings were in line with Maltby et al. (2005), who found that the intense personal aspect of celebrity worship would disappear when the fans became more mature. Maltby et al. (2005) showed that adolescent girls aged 14-16 years who had intense personal celebrity worship were more likely to have negative body image, but the correlation between celebrity worship and body image would fade in adolescents aged 17-20 years. However, a later study by Maltby and Day (2011) on young adults aged 18-23 found a different result. The study showed that participants' intense personal worship toward celebrities whose bodies were admired would predict elective cosmetic surgery over eight months, which is one of the body image problems.

The difference in the results of the two previous studies shows that the correlation between the intense personal aspect of celebrity worship and body image is determined not solely by the fans' age but also by other characteristics of the fans. There were several characteristics of K-pop girl groups fans in this study (see Table 1) that supported the insignificant correlation between the intense personal aspect and all body image dimensions. Firstly, most of the participants in this study reported that although they often wished to have bodies like idolized K-pop girl groups, the frequency they compared themselves to K-pop girl groups was only sometimes, rarely, and even never. This characteristic indicated that the participants did not have a high intense personal aspect of celebrity worship. They did not report such intense and compulsive feelings towards their 
favorite K-pop girl groups, which did not correlate with their body image. People who score highly on the intense personal aspect may be prone to causing worry or distortion in their body shape (Maltby et al., 2005). Secondly, most of the participants adored K-pop girl groups not only because of their attractive appearance and face $(71.7 \%)$ but more because of their excellent vocals $(79.7 \%)$. This characteristic also indicated that participants were not obsessed with the appearance of their favorite celebrity, which is a characteristic of the intense personal aspect, so this aspect was not correlated with the body image of the participants in this study.

All aspects of celebrity worship did not significantly correlate with appearance evaluation, overweight preoccupation, and self-classified weight dimensions of body image. These three dimensions focus more on the personal feelings and evaluation towards physical appearance, weight, and obesity (Cash, 2000). The entertainment-social aspect dominated the participants' celebrity worship in the current study (see Table 5). Participants focused more on the ability of K-pop girl groups to entertain and attract attention than merely physical appearance. Therefore, all aspects of celebrity worship did not demonstrate a significant correlation with the dimensions of appearance evaluation, overweight preoccupation, and self-classified weight. Moreover, some characteristics of participants in the current study (see Table 1) might also contribute to those insignificant correlations. These characteristics of participants include the length of worshipping K-pop girl groups, realistic weight perception, and tendency to choose healthy weight control behaviors when experiencing dissatisfaction.

Most participants had worshipped K-pop girl groups for more than 2 years (see Table 1). This quite long parasocial relationship might cause fans to have such a complete knowledge of their favorite celebrities. This knowledge includes their songs, relations, abilities, and even personal characters. Their admiration was not limited to their idols' physical appearance and was not significantly correlated with their feelings or evaluation towards physical appearance, weight, and obesity. One of the reasons most participants (71.7\%) worshiped K-pop girl groups was that they have attractive appearances and faces. In addition, most participants also reported that they often and sometimes wanted a body shape like their favorite idol. Nevertheless, cross-tabulation between participants' BMI and the self-classified weight dimension (see Table 3) showed that most participants still had a fairly realistic perception of their weight. This participant's characteristic might support the insignificant correlations between all aspects of celebrity worship and the self-classified weight dimension. Another characteristic of most participants was the tendency to choose healthy weight control behaviors, such as exercising and reducing food portions, when they were dissatisfied with their bodies. This characteristic might also support the nonsignificant correlations between aspects of celebrity worship and the overweight preoccupation dimension of body image because the dimension contained the use of unhealthy weight control behaviors, such as fasting or going on crash diets.

The median analysis on the celebrity worship aspects (see Table 5) showed that entertainment social was the most dominant aspect of K-pop girl groups fans in this study. Most of the participants reported that they always looked for information about K-pop girl groups they admired through social media such as YouTube, Twitter, and Instagram (see Table 1). Besides, most participants also supported K-pop girl groups by always or frequently listening to songs and streaming music videos, or providing direct support via the V-Live application. All activities related to K-pop girl groups would cause the participants to pay more attention to their idols' appearance and increase their orientation 
towards appearance. Adolescent fans of K-pop girl groups will pay attention and make the idols' appearance as their standard. Dewi, Agustina, and Faza (2013) explained that the Korean clothing style was considered attractive, unique, casual, and not too flashy, so adolescents imitated their idols' dressing style.

The median analysis also showed that the borderline pathological aspect was at the lowest level compared to the other two aspects of celebrity worship (see Table 5). One of the characteristics of borderline pathological celebrity worship is the willingness to spend a lot of money on the goods related to their favorite celebrity (Maltby et al., 2005). Most of the study participants reported that they never and rarely bought albums and goods or merchandise of K-pop girl groups.

The limitation of this study was related to the characteristic of the google form as a data collection medium, namely the researcher could not directly observe the participants' accuracy in filling out the questionnaire. Consequently, the researcher had to abort some participants because they wrote the K-pop boy group's name. Another limitation lay in the validity of the self-classified weight dimension of body image, which only consisted of two items. Therefore, the discrimination index could not be calculated. Suggestions for further research is that research on the same topic can be carried out on male and female fans of K-pop girl and boy groups as a comparison. In addition, research on celebrity worship and body image can also be carried out using qualitative methods to collect more in-depth data, such as what factors influence celebrity worship at the intense personal and borderline pathological levels. Fans of K-pop girl groups are suggested to idolize their favorite celebrities objectively and not excessively so as not to fall to the compulsive and pathological levels of celebrity worship.

\section{Conclusion}

Each level of celebrity worship has a different relationship with each body image dimension. Entertainment social is the most common celebrity worship among female adolescents fans of K-pop girl groups and affects young girl' body image by increasing their attention to appearance. Borderline pathological is the most extreme and dangerous celebrity worship because it negatively affects adolescent girls' body image by reducing their satisfaction with some body parts. The theoretical implication of this research is that celebrity worship can indeed affect the body image of K-pop girl group fans, especially on the dimensions of appearance orientation and body areas satisfaction. The practical implication is that celebrity worship does not negatively affect the body image of young girls fans of K-pop girl groups as long as the adoration is expressed reasonably and not excessively (intense, too personal, and pathological).

\section{References}

Bucchianeri, M. M., Arikan, A. J., Hannan, P. J., Eisenberg, M. E., \& Neumark-Sztainer, D. (2013). Body dissatisfaction from adolescence to young adulthood: Findings from a 10-year longitudinal study. Body Image, 10(1), 1-7. https://doi.org/10.1016/j.bodyim.2012.09.001

Burns, R. B. (1993). Konsep diri: Teori pengukuran, perkembangan, perilaku (Selfconcept: Theory, measurement, development, behavior). Arcan.

Cash, T. F. (2000). MBSRQ users' manual (3rd ed.). Old Dominion University Press.

Choi, E. (2018). Korean fashion media, beauty ideals, and colorism: Examining the prominence of whiteness between 2013 and 2017 in Ceci Magazine. Unpublished 
Master Thesis. IOWA State University.

Denich, A. U., \& Ifdil, I. (2015). Konsep body image remaja putri (Body image concept among teenage girls). Jurnal Konseling Dan Pendidikan, 3(2), 55-61. https://doi.org/10.29210/116500

Dewi, F. S., Agustina, H., \& Faza, R. (2013). ). Fenomena budaya Korea modern dalam cara berpakaian di kalangan remaja SMA Negeri 3 Cirebon kelas X6 (The phenomenon of modern Korean culture in dressing among teenager at SMA Negeri 3 Cirebon in X6 class). Jurnal Signal, 1(1), 1-11.

Faujiah, A. (2018). Hubungan celebrity worship dengan perilaku modeling: Penelitian pada komunitas Force Cikarang (The relationship between celebrity worship with modelling behavior: Study on Force Cikarang Community). Unpublished Doctoral Dissertation. UIN Sunan Gunung Djati, Bandung.

Giles, D. C., \& Maltby, J. (2004). The role of media in adolescent development: Relations between autonomy attachment, and interest in celebrities. Personality and Individual Differences, 36(4), 813-822. https://doi.org/10.1016/S0191-8869)03)00154-5

Greene, A. L., \& Adams-Price, C. (1990). Adolescents' secondary attachments to celebrity figures. Sex Roles, 23, 335-347. https://doi.org/10.1007/BF00289224

Heinberg, J. L., \& Thompson, J. K. (1992). Social comparison: Gender, target importance ratings and relation to body image disturbance. Journal of Social Behavior and Personality, 7(2), 335-344.

Hennida, L. J. (2013). Corporate strategies in the spread of Hallyu (Korean wave in Indonesia). Mozaik, 13(2), 117-125.

Jung, J., \& Hwang, C. S. (2016). Associations between attitudes toward cosmetic surgery, celebrity worship, and body image among South Korean and US female college students. Fash Text, 3(17). https://doi.org/10.1186/s40691-016-0069-6

Kusuma, L., \& Yuliawati, L. (2013). Self-esteem and celebrity worship on late adolescents. Anima Indonesian Psychological Journal, 28(4), 202-209.

Maltby, J., \& Day, L. (2011). Celebrity worship and incidence of elective cosmetic surgery: Evidence of a link among young adults. Journal of Adolescent Health, 49(5), 483-489. https://doi.org/10.1016/j.jadohealth.2010.12.014

Maltby, J., Giles, D. C., Barber, L., \& McCutcheon, L. E. (2005). Intense-personal celebrity worship and body image: Evidence of a link among female adolescents. British Journal of Health Psychology, 10(1), 17-32. https://doi.org/10.1348/135910704X15257

McCutcheon, L. E., Lange, R., \& Houran, J. (2002). Conceptualization and measurement of celebrity worship. British Journal of Psychology, 93(1), 67-87. https://doi.org/10.1348/000712602162454

McCutcheon, L. E., Scott, V. B., Aruguete, M. S., \& Parker, J. (2006). Exploring the link between attachment and the inclination to obsess about or stalk celebrities. North American Journal of Psychology, 8(2), 289-300.

Noky, H. M. (2015). Hubungan celebrity worship pada idola K-pop (Korean pop) dengan body image di komunitas K-pop ucee (The relationship between celebrity worship with body image among K-pop (Korean pop) idols in ucee K-pop community). Unpublished Undergraduate Thesis. Universitas Kristen Satya Wacana Salatiga.

Nurani, N. (2017). Fanatisme fans K-Pop: Candu dan bumbu remaja (Fanaticism of K-Pop fans: Opium and spices for youth). Kumparan. Retrieved from https://kumparan.com/kumparank-pop/fanatisme-fans-k-pop-candu-dan-bumbu- 
remaja/full

Santrock, J. W. (2007). Perkembangan anak (Child development). Erlangga.

Wilson, F. R., Pan, W., \& Schumsky, D. A. (2012). Recalculation of the critical values for Lawshe's content validity ratio. Measurement and Evaluation in Counseling and Development, 45(3), 197-210. https://doi.org/10.1177/0748175612440286 